\title{
SOLA EXPERIENTIA: SUATU ANALISIS TERHADAP TEOLOGI SCHLEIERMACHER
}

\author{
Marde Christian Stenly Mawikere \\ Institut Agama Kristen Negeri (IAKN) Manado \\ Jl. Bougenville Tateli Satu, Kecamatan Mandolang, Kabupaten Minahasa, Sulawesi Utara 95661 \\ Email: mardestenly@gmail.com
}

\begin{abstract}
Abstrak: Marde Christian Stenly Mawikere. This article is an analysis of the theology of Friedrich Schleiermacher, known as the Father of Modern Theology. By using qualitative research methods on various available literature that review the life and theological thinking of Schleiermacher, the author tries to reveal that the unique thinking of FriedrichSchleiermacher's theology is strongly influenced by his spiritual background, parental influence, church origin and tradition, educational patterns and the thought of his theological education and zeit geist (the spirit of the times) who were carrying the current of modern thought when Schleiermacher lived. On the one hand, Schleiermacher's theology is often considered to be liberal in the theological paradigm of reform and evangelicalism because it departs from feeling, not from the spirit of Sola Scriptura. But on the other hand, Schleiermacher's theology makes a positive contribution because it gives a place to the experience of faith (Sola Experientia) with a living God who can not only be reached with philosophia or wisdom.
\end{abstract}

Keywords: Modern Theology, concrete theology, Sola Experientia.

\begin{abstract}
Abstrak: Marde Christian Stenly Mawikere. Artikel ini merupakan analisa terhadap Teologi dari Friedrich Schleiermacher, yang dikenal sebagai Bapak Teologi Moderen. Dengan menggunakan metode penelitian kualitatif terhadap berbagai literatur yang telah tersedia yang menguraikan mengenai kehidupan dan pemikiran teologi dari Schleiermacher, maka penulis mencoba untuk mengungkapkan bahwa keunikan pemikiran Teologi Friedrich Schleiermacher yang dipengaruhi oleh latar belakang kehidupan rohaninya, pengaruh orangtua, asal dan tradisi gereja, pola pendidikan dan pemikiran pendidikan teologinya serta zeit geist (semangat zaman) yang sedang membawa arus pemikiran moderen pada waktu Schleiermacher hidup. Pada satu sisi, Teologi Schleiermacher kerap dianggap liberal dalam paradigma teologi reformasi dan evangelical karena ia berangkat dari feeling, bukan dari semangat Sola Scriptura. Namun pada sisi lain, Teologi Schleiermacher memberikan kontribusi positif sebab memberikan tempat kepada pengalaman iman (Sola Experientia) dengan Allah yang hidup yang tidak hanya dapat dijangkau dengan philosophia atau wisdom.
\end{abstract}

Kata Kunci: Teologi Moderen, Teologi yang kongkrit, Sola Experientia.

\section{PENDAHULUAN}

Perkembangan teologi Kristen tidaklah terlepas dari pengaruh dari perubahan-perubahan yang terjadi seiring dengan waktu yang terus mengarah ke depan maupun perkembangan zaman. Teologi Kristen tidak saja dipengaruhi oleh filsafat yang merupakan refleksi dari pemikiran manusia, namun dipengaruhi pengalaman hidup sehari-hari manusia dalam hubungannya dengan Allah, sesama, konteks lingkungannya bahkan eksistensi diri yang bergumul dengan realitas. Menurut Yakub Susabda, sejarah gereja telah menyaksikan bahwa dalam setiap periode sejarah manusia mempunyai pertanyaan yang berbeda-beda tentang Allah; eksistensi dan karyaNya. Karena itu, Yakub Susabda telah menyimpulkan hal ini secara garis besar sebagai berikut: Gereja jaman patriakh, yakni pada masa Bapak-bapak gereja (abad 4-5 M) yang kerap mempertanyakan noumena dari Allah. Apakah Allah yang sejati adalah Allah yang Esa? Bagaimana gereja menjelaskan imannya pada Allah, Yang Esa, yang juga pada saat yang sama, disebut Bapa, Putera dan Roh Kudus? Pergumulan jaman itu adalah pergumulan dengan masalah Trinitas. Gereja abad Pertengahan (medieval era) mempertanyakan akan eksistensi Allah. Apakah betul Allah itu ada? Bagaimana gereja dapat 
membuktikan keberadaan Allah? Hal ini terjadi karena realitas perselingkuhan antara filsafat dan teologi (dogma) Kristen pada jaman itu. Adapun Thomas Aquinas (abad $13 \mathrm{M}$ ) bisa disebut sebagai teolog dan pemimpin gereja yang mencoba untuk menjawab pertanyaan jamannya. Dengan bukti yang bernuansa filsafat yang memuat asumsi-asumsi ontologis, teleologis, causalistis, dan sebagainya, ia telah coba membuktikan tentang keberadaan Allah. Adapun Gereja jaman Reformasi menghadapi pertanyaan yang lain lagi. Para reformator seperti Martin Luther, Ulrich Zwingli maupun Johanes Calvin (abad $16 \mathrm{M}$ ) tidak lagi mempertanyakan akan eksistensi Allah yang metafisik. Bagi mereka gereja membutuhkan pengalaman dengan Allah secara pribadi (yang personal), yaitu Allah yang berdaulat, merencana, mempertimbangkan, menetapkan, memilih dan sebagainya. Johanes Calvin, dengan semangat zaman (zeist geist)-nya, mencoba mengembangkan doktrin yang berkisar sekitar "Allah yang personal". Ia mulai dengan basic premise (suatu proposisi dan asumsi dasar) tentang "kedaulatan Allah". Dari sana, Johanes Calvin menarik suatu logika berpikir, kalau Allah berdaulat berarti, Ia adalah originator dan kreator dari segala yang terjadi. Ia adalah Allah yang punya rencana dan secara aktif terlibat dibelakang setiap gejala-gejala (phenomena). Pasti Allah telah menetapkan (decrees of God) hal-hal yang akan terjadi. Oleh sebab itu tak mungkin ada sesuatu yang terjadi secara kebetulan atau di luar pengetahuan Allah. Dengan demikian Johanes Calvin bicara tentang Providensia (pemeliharaan Allah), predestinasi, election, bahkan reprobation (kebinasaan yang sudah ditetapkan bagi mereka yang tidak percaya). Ini adalah manifestasi dari semangat jamannya dimana gereja menggumuli pengenalan mereka akan Allah yang personal, yang pikiran, perasaan, kehendak dan rencana-Nya dapat dipahami manusia sejauh Ia telah menyatakan diri melalui Alkitab. Sedangkan Gereja jaman moderen (abad 1719 M) mempunyai pertanyaan yang lain lagi tentang Allah. Menurut para teolog moderen, Objective Authority (apa yang gereja, teolog dan bahkan Alkitab katakan secara harafiah) tidak menarik lagi. Adapun mereka merasakan betapa manusia sebenarnya ditentukan oleh cara berpikirnya sendiri yang otonom (rasionalisme). Oleh sebab itu pertanyaan mereka yang terutama tidak lagi pada "apa yang Alkitab katakan, atau apa yang gereja katakan," melainkan, "bagaimana manusia bisa mengenal Allah dengan rasionya sendiri?". Karena itulah semangat rasionalisme menguasai bagian pertama dari jaman moderen, dan kemudian munculnya romanticisme telah mengubah pertanyaan manusia tentang Allah. Seperti Friedrich Schleiermacher (1768-1834), bapak dari Teologi Moderen, yang hidup dalam bagian kedua dari jaman moderen ini, mengajukan suatu pertanyaan penting: "Bagaimana manusia dapat mengalami pengalaman iman yang sejati melalui perasaan (feeling)nya?" Bagi dia, pengalaman dengan Allah tidak tergantung pada rasio manusia, tetapi pada pengalaman "batiniah" atau "perasaan ketergantungan pada-Nya/ feeling of absolute dependency". Pada akhirnya Gereja abad XX adalah gereja yang mengalami kesulitan menformulasikan pertanyaan mereka tentang Allah. Apakah Allah yang telah menyatakan diri melalui Alkitab yang suffiency ataukah memerlukan pengalaman penjumpaan dengan Allah yang perlu ditekankan. Karl Barth (1886-1968), mencoba membuktikan akan kepalsuan konsep Allah yang dibangun atas pengalaman rasio dan feeling manusia. Baginya Allah adalah wholly Other yang sama sekali lain dari pada apa yang manusia rasakan, bayangkan, pikirkan dan alami. Sebenarnya Karl Barth ingin membawa gereja kembali pada konsep Allah yang trancendence. Tetapi munculnya pandangan-pandangan teologi dari Albrecht Ritscl (1822-1899), Adolf von Harnack (1851-1930), Paul Tillich (1886-1965) dan pergolakan di Amerika Selatan dengan Teologi Pembebesannya (liberation theology) telah membawa gereja kembali pada kebutuhan akan konsep Allah yang dekat dengan manusia dan ciptaan/immanence (Susabda, 1990, pp. 14-16). Pada akhirnya pengaruh teologi yang dibangun berdasarkan rasio telah melahirkan teologi liberal dan teologi yang dibangun berdasarkan pengalaman terus dikobarkan dengan hadir 
dan berkembangnya gerakan karismatik dalam kekristenan kontemporer.

Dalam artikel ini, penulis akan mencoba membahas mengenai analisis terhadap teologi Friedrich Schleiermacher yang di atas disebut sebagai bapak Teologi Moderen. Tidak semua aspek dari pemikiran Friedrich Schleiermacher akan disoroti, namun melalui tulisan ini akan memberi gambaran sekilas mengenai pandangan teologinya yang dipengaruhi dan mempengaruhi pergumulan teologi Kristen pada zaman moderen maupun zaman sesudahnya yakni pascamoderen yang menekankan pengalaman praktis ketimbang insight.

Friedrich Schleiermacher adalah teolog yang dikagumi sebagai pemikir besar abad ke XIX oleh sebagian teolog abad ke XX. Akan tetapi tidak berarti Schleiermacher selalu sukses dalam setiap hal. Kritik yang diarahkan kepada dirinya, merupakan hal yang menyatakan bahwa Teologi Schleiermacher juga memiliki berbagai keterbatasan. Teolog Neo Ortodoks yang termasyur Karl Barth adalah salah satu pengagum Schleiermacher. Kekaguman Karl Barth terhadap kebesaran pemikiran dan pengaruh Schleiermacher, dinyatakan dalam pernyataannya seperti yang dikutip oleh Tony Lane sebagai berikut: He did not found a school, but an entire age (ia tidak mendirikan sebuah sekolah, aliran/golongan, melainkan suatu zaman) (Lane, 2012, p. 198). Pernyataan ini mengisyaratkan kepiawaian dan pengaruh Schleiermacher yang tidak hanya terbatas pada sekelompok orang. Schleiermacher bukan tokoh kontemporer pendidik sebuah aliran teologi, melainkan intelektual kontemporer yang tetap menarik perhatian masyarakat teologi, khususnya para teolog akademisi. Namun ucapan pujian diatas bukanlah kalimat asli dari Karl Barth. Kalimat yang diucapkan ulang oleh Barth adalah ucapan Schleiermacher sendiri yang ia ucapkan sebagai tanda kekagumannya terhadap Frederick Agung (Brown, 2011, p. 149). Karl Barth juga mengakui bahwa Schleiermacher sebagai bapak gereja abad XIX. Pengakuan lain yang dialamatkan kepada Schleiermacher ialah bapak teologi modern, karena ia adalah pemula yang secara siste- matis memikirkan pertanyaan-pertanyaan teologis yang gereja hindari pada zaman-zaman sebelumnya. Misalnya, apakah umat Kristen masih bisa mempertahankan imannya pada Allah di tengah perkembangan dan tantangan sains modern? Bagaimana otoritas dan keabsahan Alkitab sebagi wahyu Allah di tengah pluralitas agama dunia?" Bagaimana mengalami Tuhan yang hidup di tengah masyarakat moderen maupun pascamoderen yang mana telah tersedia beragam fasilitas dan kecanggihan teknologi? Jawaban-jawaban teologis terhadap pertanyaan-pertanyaan diatas dan masih banyak pertanyaan lainnya, diformulasikan oleh Schleiermacher melalui pendekatan apologetis. Karena pemikiran teologi Schleiermacher mewarnai dunia teologi pada sepanjang abad ke XX maupun XXI ini, maka hal ini perlu untuk dideskripsikan dan dianalis sehingga pembaca zaman ini dapat mengenal dan memahami pandangan teologinya.

\section{METODE}

Artikel ini merupakan "Analisis terhadap Teologi dari Friedrich Schleiermacher". Penelitian ini dibangun dengan mengadakan telaah teoritis terhadap berbagai literatur yang relevan dengan topik yang dibahas, secara khusus literatur mengenai Teologi Moderen di Indonesia. Sumber data dalam penelitian ini adalah buku-buku yang membahas tokoh/pribadi, riwayat pelayanan, dan pemikiran, teologi dari Friedrich Schleiermacher. Adapun penelitian literatur ini kemudian diolah secara kreatif dan dinamis oleh penulis.

Setelah meneliti latar belakang kehidupan dan teologi Schleiermacher, penulis melakukan evaluasi kritis dari sudut pandang teologi injili. Latar belakang kehidupan dan teologi diperlukan untuk memberi gambaran lebih dalam terkait dengan teologi Schleiermacher. Beberapa sumber informasi dari Lane, Wellem, Brown, dan Susabda menjadi sumber referensi untuk penulis memberikan analisis terhadap teologi Schleiermacher. 


\section{HASIL DAN PEMBAHASAN}

\section{Latar Belakang Kehidupan Schleiermacher}

Fredrich Daniel Ernst Schleiermacher, begitu nama lengkapnya adalah anak seorang pendeta gereja Reformed di Silesia Utara, Jerman. Ia dilahirkan 21 November 1768 di Breslau (sekarang Polandia Selatan), (Lane, 2012, p. 198; Brown, 2011, p. 150). Ayahnya pernah menjadi pendeta tentara (Prussian Army) di Silesia Utara (Jerman Utara) sedangkan ibunya adalah seorang yang sangat saleh. Kedua kakek Schleiermacher juga adalah pendeta. Sekalipun ayahnya adalah seorang pendeta Reformed (Calvinis), namun ia sangat dipengarui oleh aliran pietisme dari orang-orang Moravian. Bagi ayahnya, inti dari agama Kristen terletak pada pengalaman batiniah secara mistik dari human consciousness dengan Allah yang disaksikan Alkitab. Menurut iman ayahnya, doktrin-doktrin gereja seperti inkarnasi dan penebusan darah Yesus Kristus benar-benar mutlak penting karena Allah adalah Allah yang menyatakan diri-Nya dalam dan melalui apa yang disaksikan Alkitab. Oleh karena itu, satu-satunya jalan untuk dapat mengenal Allah adalah mengenal kebesaran Allah seperti yang disaksikan Alkitab dan mengalaminya secara batiniah (encountering between the inner self with God), (Susabda, 1990, p. 5). Dengan demikian Schleiermacher dibesarkan dalam suasana kerohanian Calvinis bercorak pietis. Dengan kata lain perjalanan hidup Schleiermacher dimulai dengan begitu baik yakni dalam keluarga yang mengakui Kedaulatan Allah dan berpusatkan pada Tuhan Yesus Kristus.

Akan tetapi pandangan iman dari orangtuanya ini tidak diikuti oleh Schleiermacher sebab ia tumbuh ditengah zaman yang disebut sebagai zaman pencerahan (age of reason/enlightenment yang dalam bahasa Jerman disebut Aufklarung). Adapun pada zaman ini disebut juga jaman akal budi/fajar budi karena segala penelitian, mulai dari proses sampai kepada hasil penelitian/kesimpulan, termasuk apa yang disebut sebagai "kebenaran" diukur dengan menggunakan rasio. Schleiermacher juga dibesarkan di tengah paham Romanticisme yang sangat menguasai, mempengarui pemikiran dan kebudayaan masyarakat di seluruh daratan Eropa. Karena itu, ia menyimpulkan bahwa Allah tidak mungkin menjadi obyek dari rasio sama seperti benda dan realitas alami. Allah hanya dapat menjadi obyek dari kesadaran batin (human consciousness). Pengalaman yang sejati dengan Allah hanya dapat dialami dan dirasakan (Susabda, 1990, pp. 4-5).

Adapun Schleiermacher hidup pada masa yang mana rasionalisme pencerahan dan romanticisme mempengaruhi seluruh cara berpikir manusia di Eropa. Sekalipun demikian, bagi Schleiermacher yang memiliki latar belakang pietis, rasionalisme itu sendiri tidak memberikan jawaban atas kebutuhan manusia untuk mengenal dan memiliki pengalaman yang otentik dengan Allah. Dengan pengaruh dari pembelajarannya akan pandangan filsafat Immanuel Kant, Schleiermacher mulai menyadari bahwa penjelasan rasional mengenai Allah merupakan hal yang tidak bakal diterima oleh dunia ini. Sekalipun Allah benar-benar telah menyatakan diri-Nya pada manusia, namun pengalaman tersebut tidak mungkin menjadi obyek rasio manusia. Pengalaman dengan Allah tidak mungkin dapat dijelaskan secara rasional (Susabda, 1990, pp. 13-14).

\section{Latar Belakang Pendidikan Schleiermacher}

Pada waktu Schleiermacher berusia 15 tahun (1783), ia mulai menikmati pendidikan pada sebuah seminari Moravian di Niesky. Seminari ini bercorak pietisme tradisi Spener yang menekankan Alkitab dan kesalehan pribadi. Pada saat tersebut, Schleiermacher sungguh menikmati secara mendalam pembelajarannya di Seminari dari Gereja Persaudaraan Moravian tersebut. Karena itu, Schleiermacher berkata: "Kehidupan dan ajaran Moravian adalah kehidupan Kristen yang begitui ideal baginya". Pada awal pembelajaran di seminari Moravian, Schleiermacher menjadi orang yang benar-benar mencintai Yesus Kristus. Kemudian setahun kemudian pada usia 17 (1785), atas anjuran ayahnya Schleiermacher pindah belajar pada seminari teologi Moravian di 
Barby. Tujuannya agar Schleiermacher bertumbuh dalam pemahaman piestis yang alkitabiah sehingga menjadi pelayan yang menjadi berkat bagi orang banyak dan pelayan yang menyenangkan hati Allah. Pada masa inilah Schleiermacher membaca tulisantulisan para filsuf seperti karya Immanuel Kant yang pada awalnya bertujuan supaya menjadi penangkal bagi pengaruh perkembangan sains dan filsafat terhadap teologi Kristen. Namun Schleiermacher memberi reaksi yang berbeda terhadap Kant. Ia juga memberi reaksi penolakan terhadap pendidikannya yang piestis. Pemikirannya banyak terjadi perubahan pada saat ia menggabungkan pengaruh agama bercorak piestis injili dengan sikap moderat liberal atas anjuran kaum terpelajar di zamannya (Brown, 2011, p. 150).

Kemudian pada tahun 1787 dari seminari theologia Moravia, Schleiermacher belajar studi teologi di Universitas Halle yang kemudian menjadi pusat pemikiran radikal (liberal) di Jerman. Di Kampus Universitas Halle, Schleiermacher mendalami pemikiran-pemikiran filsafat dari Immanuel Kant yang kritis (Hardiman, 2015, p. 28) dan filsafat klasik Yunani seperti Plato dari literatur dan para guru besar serta mempelajari karya tulis para filsuf moderen seperti Spinoza, Leibnitz, Fichte dan Schelling (Wellem, 2011, p. 168). Pada usianya yang ke 22 tahun 1790, Schleiermacher menempuh ujian teologi di Universitas Halle yang kemudian membawa ia untuk menempuh pendidikan teologi selanjutnya di Universtias Berlin. Pada kedua perguruan tinggi tersebut yakni di Universitas Halle dan Berlin, tidak luput dari pemikiran filsafat rasionalisme dan teologi liberal yang kemudian sangat mempengaruhi kehidupan dan pemikiran teologi Schleiermacher. Terjadilah pergeseran dan pencampuran dari latar belakang keluarga dan kehidupan kerohanian yang bercorak Reformed-Pietis kepada pemikiran intelektual pencerahan dalam teologi Schleiermacher.

\section{Pelayanan Schleiermacher Sebagai Pendeta dan Teolog}

Setelah menyelesaikan pendidikan teologinya, selanjutnya Schleiermacher melayani sebagai pendeta di gereja Reformed (Calvinis) di Prussia Barat. Adapun tahun 1793 Schleiermacher pindah melayani di Berlin. Mulai tahun 1794 Schleiermacher ditahbiskan untuk melayani sebagai pendeta tetap pada rumah sakit Kharitas(Charity) di Berlin. Pada waktu itu, Berlin merupakan pusat dari penelitian dan perkembangan dari pencerahan (Enlightenment/Aufklarung). Di Berlin, Schleiermacher bersahabat karib dengan Friederich von Schlegel seorang romantisisme dan pemimpin serta pemikir yang cerdas namun aneh (dikelilingi oleh perempuan). Pada periode ini Schleiermacher memulai suatu babak baru dalam perjalanan hidupnya yang mana ia menjadi anggota kelompok kaum intelektual muda yang anggota-anggotanya terdiri dari berbagai cendekiawan dari berbagai paham/aliran seperti rasionalisme dan romantisisme. Mereka adalah para pemikir yang menentang teologi ortodoks sekaligus merupakan perkumpulan para penulis dan pujangga Romantik yang memberontak melawan pandanganpandangan rasionalis dari pencerahan. Penekanan kelompok ini adalah kepada peranan misteri, imajinasi serta perasaan sehingga ikut mempengaruhi Schleiermacher dalam merumuskan pandangan teologinya. Adapun Schleiermacher bergumul bagaimana memenangkan orang-orang seperti mereka itu supaya berbalik kepada gereja (Wellem, 2011, p. 168).

Adapun pada tanggal 18 Pebruari 1804, Schleiermacher menjadi pendeta yang melayani di Pomerania serta diangkat menjadi guru besar yunior (junior professorship) di Universitas Halle yang ia jalani selama lima tahun lamanya. Karir Schleiermacher cepat menanjak. Schleiermacher memperlihatkan pemikirannya yang sangat tepat dalam berbagai topik yang tercantum dalam kurikulum Halle. Pada Tahun 1806, Schleiermacher memberi kuliah umum dalam bidang filsafat Yunani di Universitas Halle. Pada tahun 1809, Schleiermacher meninggalkan Universitas Halle dan kembali ke Universitas Berlin. Pada tahun 1810, Schleiermacher ikut mendirikan Universitas Berlin. Di Universitas Berlin, Schleiermacher diangkat menjadi profesor dan dekan fakultas teologi. Selain melayani sebagai akademikus, 
Schleiermacher menjadi pendeta di Dreifaltigkeitkirche. Dalam pelayanan penggembalaannya, Schleiermacher ikut mempersiapkan Bismarck, negarawan besar dari Prusia untuk disidi. Tugasnya tersebut dilaksanakan oleh Schleiermacher sampai ia meninggal pada tahun 1834 (Lane, 2012, p. 198; Wellem, 2011, p. 168).

Seperti yang telah diungkapkan di atas, Schleiermacher sangat giat ikut serta dalam gerakan dan perkumpulan penulis pujangga yang cerdas dari gerakan Romantisisme. Atas anjuran sahabatnya bernama Friederich von Schlege, maka Schleiermacher mulai menulis. Dalam periode pengaruh romantisisme, maka pada tahun 1798 Schleiermacher menulis bukunya yang terkenal dengan judul On Religion Speechs to its Cultured Despisers (Uraian-uraian tentang agama orang-orang beradab diantara para penghinanya). Setahun kemudian (1799) buku On Religion Speechs to its Cultured Despisers diterbitkan. Buku ini merupakan buku apolegetika dan polemik yang ditujukan pada umat non Kristen dan dapat dianggap sebagai permulaan teolog liberal. Dalam buku On Religion Speechs to its Cultured Despisers ini, Schleiermacher berupaya membela agama Kristen melawan pandangan skeptis, namun konsep agama yang ia bela radikal baru (Lane, 2012, p. 198).

Sebenarnya teologi bukanlah satu-satunya minat dari Schleiermacher. Di Universitas Berlin, Schleiermacher menerjemahkan beberapa jilid karangan filsafat dari Plato yang menjadi edisi baku dalam ilmu filsafat klasik di Jerman. Kendati demikian, ia lebih dikenal sebagai teolog dan pengkhobah ketimbang sebagai filsuf (Hardiman, 2015, p, 29). Pada saat Schleiermacher melayani sebagai pendeta di Holy Trinity Church, sebuah gereja yang moderat di Berlin, ia juga menulis naskah-naskah yang ia persembahkan kepada Akademi llmu Pengetahuan Prusia (The Prussian Academy of Sciences). Selain itu, Schleiermacher juga menulis buku dogmatika berjudul Life of Jesus dan The Christian Faith. Adapun seluruh karya tulisnya sebanyak 30 jilid yang terdiri dari khotbah-khotbah, tulisan-tulis- an teologis dan tulisan-tulisan filsafat. Dalam bidang sastra, Schleiermacher juga menulis novel yang berisi pemikiran romantis yang berkualitas tinggi yaitu Monologen (Soliloquies) yang berarti monolog atau dialog dengan diri sendiri yang merupakan sebuah novel yang mengisahkan mengenai pergumulan dan pertumbuhan pribadi.

\section{Teologi Schleiermacher}

\section{Teologi mengenai Agama}

Seperti yang telah diungkapkan di atas bahwa pandangan teologi Schleiemermacher didasarkan pada pemikiran filsafat Romantisisme. Berkaitan dengan agama atau teologi maka terdapat dua pertanyaan utama dalam filsafat Romantisisme, diantaranya adalah: What is Religion? dan What is Christianity? Romantisisme merupakan suatu gerakan yang muncul sebagai reaksi terhadap pemikiran abad pencerahan yang mementingkan akal semata-mata (rasionalisme). Para penganut aliran romantik tidak menekankan atau mengutamakan akal (knowledge), melainkan cenderung menekankan perasaan (feeling) di dalamnya termasuk intuisi dan empati. Adapun gerakan romantik yang diikuti Schleiermacher ini, sangat kuat mempengaruhi teologinya dengan memberikan penekanan terhadap perasaan (feeling). Menurut Schleiermacher jiwa adalah sebagai tempat pengalaman hidup rohani di dalam gereja Kristen dengan metode intropeksi bukan dengan metode mendengarkan Firman Allah.

Adapun pengaruh masa lalu keluarga dan corak gereja dan pelayanan ayahnya ikut memberi kontribusi mengenai pandangan Schleiermacher mengenai agama. Dengan berangkat dari latar belakang keluarga dan pendidikan corak pietisme telah mengajar padanya bahwa agama lebih daripada hanya sekedar teologi dan etika, pengetahuan dan tindakan serta mengetahui dan berbuat yang tepat. Menurut Schleiermacher yang disebut sebagai kesalehan tidaklah mungkin hanya berupa naluri yang mendambakan fragmen-fragmen metafisika dan etika yang berantakan. Menurut Schleiermacher, agama termasuk 
sebuah dunia ketiga yaitu dunia perasaan (feeling) didalamnya termasuk intuisi dan empati. Baginya, agama sejati adalah rasa dan selera untuk yang tak terhingga. Nampaknya, Schleiermacher melampaui pemahaman dan posisi pietisme tradisional. Pietisme menyatakan bahwa agama meliputi lebih daripada hanya pengetahuan dan tindakan, sedangkan Schleiermacher memahami agama sebagai sesuatu yang jelas berbeda dari pengetahuan dan tindakan (Lane, 2012, p. 198).

Dengan menyatakan bahwa agama berbeda dari pengetahuan dan tindakan, tidaklah berarti bahwa agama tidak memiliki kaitannya dengan pengetahuan dan tindakan. Namun sebaliknya agama pada hakikatnya merupakan dasar sesungguhnya dari pengetahuan dan tindakan. Agama secara esensial adalah masalah perasaan (feeling). Dalam pemikiran teologi Schleiermacher, esensi agama terletak di dalam perasaan yang bergantung mutlak (feeling of absolute dependency/sense of absolute dependence) kepada Allah. Adapun bagi Schleiermacher, feeling of absolute dependency adalah semacam bakat alami (natural gift) yang terdapat dalam setiap manusia yang merupakan satu-satunya sarana yang manusia miliki untuk dapat mempunyai pengalaman yang sejati dengan Allah bahkan inti dari natur agama yang sejati terletak pada unsur feeling of absolute dependency ini (Susabda, 1990, p. 18). Perasaan yang demikian dapat dipahami secara filsafat sebagai rasa yang dimiliki oleh setiap manusia dalam kesinambungan hubungan dengan roh dunia yang menyatu dengan Allah. Segala perbedaan yang ada dalam dunia/alam pada dasarnya mempunyai akar yang sama. Pemahaman ini seolah-olah mengindikasikan bahwa sebenarnya pendekatan Schleiermacher cenderung kepada mistikisme atau pantheisme, akan tetapi sebenarnya Schleiermacher sedang menekankan bahwa agama maupun Tuhan adalah real dalam hubungannya dengan manusia. Dengan kata lain, manusia seyogyanya memiliki pengalaman real dengan Tuhan di dalam kehidupan keagamaannya, lebih dari sekedar keberagamaan yang nominal, formal dan rutinitas.
Adapun Schleiermacher mempercayai bahwa pengalaman yang sejati dengan Allah hanya dapat menjadi obyek "pengalaman/experience". Manusia dapat benar-benar mengalami pengalaman yang sejati dengan Allah melalui salah satu aspek dalam diri manusia yakni "kedalam hidup/inner self" manusia. Suatu momentum pengalaman dengan Allah akan dialami manusia pada waktu manusia benarbenar secara tulus sadar akan dosanya dan merindukan untuk diperdamaikan dengan Allah (consciousness of sin and redemption) dan manusia tidak lagi terjerat dalam kedagingannya (quietness and tranquility). Karena itu, maka Schleiermacher mempercayai bahwa natur yang sejati dari kehidupan beragama tidaklah berada pada tataran rasio dan tindakan/tingkah laku agama melainkan pada pengalaman intuitif/feeling dengan Allah (Susabda, 1990, p. 14).

Menurut Schleiermacher, doktrin dan dogma bukanlah agama. Doktrin dan dogma tidak perlu bagi agama itu sendiri serta hampir-hampir tidak perlu untuk menyampaikan agama. Akan tetapi, teologi tidak dapat dihindari dan merupakan keprihatinan yang pantas untuk melakukan refleksi atas agama. Sekalipun agama bukan pengetahuan, namun terdapat pengetahuan mengenai agama, yaitu teologi. Orang-orang yang berkeberatan terhadap agama karena ketidakjelasan yang picik dari beberapa teolog, tidak memahami bahwa teologi dan agama adalah merupakan dua hal yang berlainan. Agama tidaklah terdiri dari sejumlah dogma atau sejumlah preposisi intelektual yang kepadanya orang-orang percaya menyatakan persetujuannya, namun agama muncul dari perasaan dan pengalaman keagamaan. Pengalaman keagamaan yang bersifat batiniah (psikologis) yang mencakup pengalaman perseorangan dan pengalaman persekutuan Kristen. Dari pengalaman seperti inilah maka rumusan-rumusan iman/kredo bahkan dogma telah dan akan dirumuskan. Akan tetapi rumusan-rumusan tersebut hanya bersifat sekunder apabila dibandingkan dengan perasaan dan pengalaman keagamaan seseorang dan persekutuan Kristen (Wellem, 2011, p. 168). 
Lebih jauh lagi menurut Schleiermacher, dogma adalah suatu pernyataan tentang feeling dan bukan pernyataan mengenai Allah. Adapun yang menjadi tempat secara psikologis dari kesalehan Kristen menurut Schleiermacher adalah perasaan (feeling) yakni kesadaran diri yang langsung. Perasaan diri harus diintropeksi. Perasaan ini ialah perasaan akan kebergantuannya yang mutlak. Disitulah terdapat asal dan pusat agama. Bagi Schleiermacher, perumusan dogma tidak mungkin secara langsung membicarakan mengenai Allah atau dunia. Rumusan dogma mengenai Allah dan dunia dapat dipahami hanya melalui penjelasan mengenai keberadaan manusia secara eksistensial. Dengan demikian Schleiermacher sepertinya menjadikan perasaan (feeling) sebagai dasar pemahaman untuk memahami Allah dan dunia. Pendekatan ini bersifat antroposentris yang menyatakan bahwa manusia tetap menjadi pusat berfilsafat maupun berteologi. Apabila pencerahan sangat menekankan rasio/pikiran maka Schleiermacher menekankan perasaan/feeling. Seperti halnya keyakinan para penganut romantik mengenai eksistensi manusia, dunia dan Allah maka Schleiermacher pernah berkata: "Segera aku mengarahkan pandangan ke dalam kepada diriku yang paling dalam, maka segeralah aku berada di dalam kawasan kekekalan". Kesadaran akan perasaan kebergantungan yang mutlak adalah kesadaran berada dalam hubungan dengan Allah. Dalam pemahaman Schleiermacher tersebut, perasaan (feelingi) atau "pengalaman manusia" menjadi kanon/tongkat pengukur untuk menilai seluruh pengajaran agama Kristen.

Dengan menganulir pemahaman rasional mengenai doktrin dan kebenaran-kebenaran Alkitab sebagai bahan pengalaman iman Kristen, maka menurut Schleiermacher pengalaman yang sejati dengan Allah hanya dapat manusia alami pada saat ia mengadakan exercise feeling of absolute dependency, yakni melatih kepekaan akan kehadiran dan ketergantungan pada Allah melalui hati nurani yang tulus dan bersih. Apabila manusia mengalami penghinaan dan pengkhianatan dari manusia lainnya maka ia mempunyai dua pilihan yakni memakai perasaan atau emosi (feeling) untuk melampiaskan kemarahan, kebencian dan balas dendam atau memakai $f e$ eling of absolute dependency, mencari hadirat Allah, mematikan kebencian tersebut dan belajar mengasihi dan mengampuni dengan ketulusan hatinya. Dengan memilih untuk memakai feeling of absolute dependency tersebut, maka akan memberikan kepada manusia pengalaman yang sejati dengan Allah. Adapun Schleiermacher menganjurkan dua cara untuk melatih kerja dan kepekaan dari feeling of absolute dependency yakni kesadaran akan dosa dan kehausan untuk memperoleh perdamaian dengan Allah/ consciousness of sin and redemption serta melalui pengalaman mistik dengan kehadiran Allah melalui meditasi/quietness and tranquility (Susabda, 1990, pp. 18-19).

Pendekatan Schleiermacher terhadap agama tersebut adalah pendekatan yang sama sekali baru. Keyakinan kaum pietisme bahwa agama itu perlu dirasakan dan dialami, oleh Schleiermacher telah dikembangkan dengan begitu jauh sehingga pada akhirnya agama itu dikenakan kepada perasaan (feeling) dan pengalaman (experience) yang didalamnya termasuk intuisi dan empati manusia. Percaya (trust/believe) dalam arti menerima doktrin dan dogma tertentu menjadi sesuatu yang asing dan tidak bermakna bagi agama. Inilah konsep baru dalam kekristenan yang dalam pandangan ortodoks teologi Kristen dipahami sebagai suatu riwayat mengenai wahyu/penyataan Allah sebagaimana yang telah dinyatakan dalam Alkitab, tradisi, alam maupun kombinasi dari ketiganya. Sedangkan Schleiermacher menjadikan teologi sebagai penelitian agama, yaitu suatu penelitian mengenai pengalaman-pengalaman keagamaan manusia (Lane, 2012, p. 199).

Adapun implikasi dari rumusan teologi Schleiermacher berkaitan dengan agama adalah sebagai berikut: Pertama, Schleiermacher membuka pintu bagi suatu corak agama dan kekristenan yang tidak lagi menerima ajaran Alkitab sebagai tolak ukur. Kedua, pemahaman Schleiermacher tersebut merupakan suatu serangan kepada dogma gereja, sebab teologinya yang menekankan perasaan/feeling 
diri manusia berarti tidak lagi terikat pada norma di luar manusia seperti doktrin dan dogma yang merupakan warisan tradisi. Ketiga, semua doktrin Kristen disusun berdasarkan kriteria filosofis. Akan tetapi perlu disadari bahwa konteks di mana doktrin ini disusun,tidak sesuai dengan penyataan Allah (devine relevation), tidak sesuai dengan karya Allah di dalam sejarah penebusan, tetapi semata-mata berdasarkan pengalaman manusia. Menurut Schleiermacher, pengalaman manusialah (spiritual experience) yang menjadi dasar perumusan doktrin (Horton, 2004, pp. 66-67). Doktrin-doktrin Kristen adalah laporan mengenai perasaan-perasaan keagamaan Kristen dalam bentuk perkataan. Keempat, gaya yang mendominasi penampilan agama kristen masa kini adalah pengalaman-pengalaman orang Kristen dan bukan lagi kemutlakan anugerah Allah, dan juga bukan penyataan Allah didalam sejarah sebagaimana yang dinyatakan dalam Alkitab. Bagi Schleiermacher esensi agama adalah pengalaman termasuk agama Kristen. Penyebab seseorang beragama adalah perasaan (feeling). Yesus Kristus adalah penebus yang merobah kesadaran perasaan dan pengalaman manusia melalui khotbah/pemberitaan Firman Allah. Kelima, Alkitab lebih diperlakukan sebagai riwayat pengalaman agama manusia daripada sebagai penyataan dari Allah maupun riwayat mengenai tindakan-tindakan Allah dalam sejarah.

\section{Teologi mengenai Alkitab}

Dalam semangat pergumulan teologi romantisisme, maka bagi Schleiermacher Alkitab adalah kesaksian-kesaksian atau berita-berita dari para tokoh-tokoh yang memiliki pengalaman batiniah dengan Tuhan. Alkitab merupakan berita mengenai pengalaman-pengalaman ketimbang sebagai wahyu/penyataan Allah yang memiliki otoritas. Karena itu pendekatannya dalam berteologi bukan berdasarkan Alkitab yang merupakan wahyu Allah secara normatif, melainkan secara eksistensial yaitu melalui pengalaman pribadi manusia dengan apa yang terjadi secara pribadi/perseorangan maupun persekutuan/komunitas. Nampaknya dengan pendekatan ini,
Schleiermacher sedang mengupayakan untuk mempersatukan Gereja-gereja Lutheran yang bercorak pietis dengan Calvinis yang sangat idealist dalam berteologi (Wellem, 2011, p. 169).

Sebenarnya dengan berpandangan demikian, maka Schleiermacher tidak hanya mereduksi atau membicarakan Alkitab sebagai suatu kisah mengenai campur tangan Allah dan sekumpulan ucapan Allah dalam menyatakan kehendak-Nya, melainkan juga sebagai kitab yang menyampaikan mengenai pengalaman dan peristiwa dari para tokoh Alkitab maupun ide atau gagasan mengenai pengalaman beragama itu sendiri. Alkitab menjadi kitab yang terbuka bagi Schleiermacher untuk melakukan analisa terhadap pengalaman keagamaan manusia yang kemudian ditafsirkan kembali menjadi rumusan iman Kristen yang dapat diterima oleh manusia moderen yang penuh pergumulan rasional maupun emosional.

\section{Teologi mengenai Tuhan}

Pada satu sisi, Schleiermacher mengakui Allah adalah Allah yang immanent, namun ia mempertanyakan kemungkinan kehadiran Allah menjadi bagian dan obyek dari hukum alam (natural law). Namun pada sisi yang lain Schleiermecher mengakui pula bahwa Allah adalah Allah yang transcendent, sambil kembali ia mempertanyakan bagaimana pengalaman manusia dengan Allah yang supranatural dan transcendent tersebut bisa menjadi pengalaman yang sejati dalam hidup manusia (Susabda, 1990, p. $10)$.

Schleiermecher mendasarkan pemikiran teologinya mengenai Tuhan pada prapaham bahwa antara Allah dan manusia terdapat jurang yang tidak mungkin dijembatani oleh manusia. Karena itu, menurut Schleiermecher manusia tidak dapat memahami dan mengenal Allah, apabila Tuhan tidak menyatakan diri-Nya. Menurut Schleiermecher, manusia tidak mempunyai pengetahuan (knowledge) yang obyektif dalam pengenalan akan Tuhan. Apabila Tuhan menyatakan diri melalui hal-hal yang bersifat supranatural, seperti keajaiban mujizat, maka manusia dimungkinkan untuk mengenal-Nya. Allah dapat di- 
kenal melalui penyingkapan/penyataan diri-Nya yang melampaui kekuatan pengetahuan rasional manusia. Adapun manusia dapat mengenal dan mengetahui Allah dalam hubungan dengan diri manusia itu sendiri, dalam kebergantungan yang absolut kepadaNya dan dalam hubungan dengan Allah dan alam semesta. Bagi Schleiermecher, Allah adalah kekal, mahakuasa dalam pengertian bahwa Allah dapat berbuat apa saja yang Ia kehendaki. Allah adalah pencipta dan mengetahui segala sesuatu (Wellem, 2011, p. 168).

Menurut Schleiermacher, Allah dapat dikenal hanya di dalam analogi yang pasti antara mengenal (knowing) dan merasakan (feeling). Sebagai knowing, subjek di tentukan oleh obyek melalui feeling, yang mana subjek itu sendiri menjadi keberadaan yang ditentukan oleh obyek. Maksudnya, feeling merupakan kehadiran yang menyeluruh,eksistensi personal yang tak terbagi, bersifat rohani, kesatuan pribadi manusia dengan akal sehatnya dan dunia rohani. Dengan demikian maka dalam pemahaman Schleiermacher tersebut, tidak ada penyebutan "agama Kristen" sebagai agama diantara agama-agama yang lain sebab agama yang sejati menyangkut kesalehan yang dirasakan dan dialami. Menurut Schleiermacher, kesalehan tersebut dimaknai sebagai "perasaan bergantung yang mutlak/ feeling of absolute dependency" kepada Allah.

Adapun pengalaman yang sejati dengan Allah, menurut Schleiermacher ditandai dengan munculnya feeling "kehangatan kasih" yang spontanitas atau tanpa dibuat-buat serta keterlibatan pribadi secara penuh. Pengalaman yang sejati dengan Allah tersebut akan dialami apabila manusia mempraktekan kasih yang tulus terhadap sesamanya. Apabila manusia dengan penuh kesungguhan mengasihi sesamanya, maka ia akan merasa bahagia (happiness) yang merupakan saat-saat penjumpaan dengan Allah (moments of encountering with God). Hal ini akan memberikan perasaan ketergantungan yang mutlak/feeling of absolute dependency terhadap Allah. Menurutnya, perbuatan kasih tersebut adalah aspek yang menyatukan seluruh umat manu- sia di seluruh dunia. Oleh karena hanya melalui kesadaran akan kenyataan adanya kehadiran Allah yang menyatukan manusia dengan sesamanya itulah, menjadi jalan untuk menemukan "penemuan diri seutuhnya" (the true individuality) dalam kehidupan manusia menjadi terbuka. Dengan demikian terdapat kaitan yang erat antara "penemuan diri seutuhnya" (the true individuality) yang diperoleh melalui pengalaman kasih yang sejati dengan pengalaman kehadiran Allah dalam kehidupan manusia (Susabda, 1990, pp. 11-12). Pada akhirnya Schleiermacher berkesimpulan bahwa pengenalan manusia akan keberadaan Allah, hanya mungkin melalui tindakan-tindakan perenungan (kontemplasi) sebab agama adalah kontemplasi sejati (religion is essentially comtemplative).

\section{Teologi mengenai Yesus Kristus}

Berkaitan dengan doktrin mengenai Tuhan Yesus Kristus, maka menurut Schleiermacher, Yesus Kristus adalah manusia biasa yang secara kebetulan dipilih oleh Allah untuk tidak mewarisi dosa asal, maka sejak lahir Ia mampu mempertahankan dan mengembangkan kehidupan rohani-Nya (spiritual consciousness). Adapun spiritual consciousness merupakan kesadaran batiniah yang adalah satu-satunya sarana (means) untuk mengenal dan bersekutu dengan Allah. Maka menurut Schleiermacher, Yesus Kristus disebut anak Allah karena di dalam dirinya kesadaran batiniah akan Allah yang merupakan bakat alami yang berupa God consciousness dapat berkembang dan mencapai kepenuhan. Yesus Kristus berbeda dari manusia-manusia yang lain oleh karena Yesus Kristus memiliki kesadaran batiniah akan Allah yang tidak dicemari oleh dosa (Horton, 2004, pp. 479-480; Susabda, 1990, p. 10). Berdasarkan kesadaran kepenuhannya, maka Ia disebut anak Allah. Dengan kata lain bagi Schleiermacher, Yesus Kristus memang memiliki keunikan atau manusia yang istimewa. Namun keunikan Yesus Kristus tidaklah terletak kepada Pribadi-Nya sebagai Allah-manusia melainkan eksistensi Yesus Kristus yang mana Ia dikuasai oleh kesadaran akan Allah yang belum per- 
nah dimiliki oleh manusia mana pun sebelumnya dan tidak akan pernah ada sesudahnya. Menurutnya, kesempurnaan Yesus Kristus oleh karena Allah berkenan hadir di dalam Dia. Oleh karena itu, Kristus adalah manusia dan bersifat ilahi. Penebusan Yesus Kristus bekerja melalui sesuatu kekuatan dan tanpa kekuatan tersebut maka manusia tidak dapat mencapai tujuan yang Allah telah tetapkan bagi mereka. Oleh sebab Yesus Kristus adalah manusia yang sempurna maka hal tersebut dapat memungkinkan manusia untuk bersekutu dengan Dia dan dosa manusia dapat diatasi oleh kesadaran akan Allah yang sedang bekerja di dalam manusia tersebut. Adapun pengalaman penebusan dalam setiap pribadi manusia melibatkan respons dalam iman dan kasih yang kemudian melahirkan pembenaran dan penyucian. Dengan demikian bagi Schleiermacher, kelahiran dan pertumbuhan iman dalam kehidupan orang-orang yang percaya terjadi di dalam pengalaman melalui Yesus Kristus (Wellem, 2011, p. 169).

Pendekatan Kristologi Schleiermacher seperti di atas memang tidaklah berdasarkan doktrin yang dirumuskan melainkan menggunakan metode pengalaman mengenai pribadi Yesus Kristus. Menurutnya, seseorang tidak boleh memberikan harkat yang lebih tinggi kepada pribadi Yesus Kristus melebihi apa yang menjadi kebutuhan aktivitas-Nya (karya-Nya). Sebab bagi Schleiermacher, apabila Yesus Kristus yang karya penebusan-Nya di sebut sebagai Allah/Tuhan, maka seolah-olah sama dengan seorang pangeran yang mengepel lantai dalam istana. Namun pada sisi yang lain, kita juga tidak dapat menghubungkan Yesus Kristus dengan suatu aktivitas yang tidak sesuai dengan harkat-Nya sebab apabila demikian maka aktivitas yang dilakukan oleh Yesus Kristus sebenarnya bukan karya-Nya sendiri. Dengan demikian bagi Schleiermacher, Yesus Kristus hanyalah seorang manusia yang berjalan sedemikian dekat dengan Allah sehingga dapat dikatakan bahwa Allah tinggal di dalam Dia. Agaknya, sikap ambigu dari Schleiermacher tersebut pada satu sisi merupakan suatu keinginan untuk menghubungkan antara pribadi dan karya Yesus Kristus, namun pada sisi lain justru memandang rendah terhadap Pribadi dan Karya Yesus Kristus (Lane, 2012, p. 200).

\section{Teologi mengenai Manusia, Dosa dan \\ Keselamatan}

Berkaitan dengan doktrin manusia (antropologi), maka Schleiermacher meyakini bahwa manusia adalah mahluk yang sempurna, tetapi pada saat yang sama adalah juga makhluk yang berdosa (Man was both originally perfect and originally sinful). Kesempurnaan manusia disini dalam arti ia mempunyai kesadaran akan hubungannya dengan Allah dan dapat mengkomunikasikan kesadaran itu kepada sesamanya. Namun manusia juga adalah mahluk yang berdosa oleh karena sebelum spiritual consciousness manusia tersebutberkembang, kuasa kedagingan lebih dahulu melumpuhkan dan menghancurkan segala keinginan baiknya. Menurut Schleiermacher, kesadaran batiniah/spiritual consciousness dari manusia sebenarnya merupakan bagian dari proses perkembangan secara alami (man's natural developmental process). Bakat untuk mengenal dan bersekutu dengan Allah tumbuh sebagai bagian dari proses kematangan pribadi.Jika demikian maka menurutnya seorang anak kecil belum memiliki kesadaran batiniah/spiritual consciousness. Lebih lanjut Schleiermacher meyakini bahwa setiap manusia mempunyai sinful nature sebagai dosa asal, sehingga sebelum spiritual consciousness tersebut tumbuh, kuasa kedagingan sudah menjadi lebih kuat. Maka setiap pribadi manusia mungkin saja tidak dapat benar-benar mengenal Allah tanpa pertolongan Yesus Kristus (Susabda, 1990, p. 24).

Sebenarnya pandangan Schleiermacher mengenai manusia tidak terlepas dari pandangannya mengenai penciptaan dunia. Menurutnya dunia dan manusia yang diciptakan oleh Allah pada mulanya adalah baik. Dosa adalah ketergantungan manusia pada diri manusia sendiri yang seringkali mencari kepuasan bagi dirinya dan bukan kepada Allah. Dosa bukan saja berasal dari tindakan-tindakan pribadi manusia, namun merupakan suatu kecenderungan yang tidak dapat dilepaskan dalam diri ma- 
nusia. Karena dosa manusia menjadi asing dari Allah sehingga memunculkan ketakutan terhadap Allah sebagai hakim yang mengetahui bahwa manusia yang berdosa tersebut layak untuk menerima hukuman Allah (Wellem, 2011, p. 168). Menurutnya, dosa pada dasarnya adalah suatu pemahaman atau indra kesadaran (sensous consciousness) yang olehnya manusia menjadi keasyikan dengan dunia sehingga tidak mengalami ketergantungan secara total kepada Allah (feeling of absolute dependency) dan kesadaran akan Allah (God consciousness). Dosa bukanlah begitu banyaknya pelanggaran terhadap hukum Allah melainkan suatu natur manusia yang lebih rendah yang menginginkan keberadaan yang bebas, pada waktu manusia itu seharusnya terikat. Manusia tidak lagi bergantung pada Allah melainkan pada diri manusia sendiri. Dengan demikian manusia dalam keadaan tanpa Allah atau dalam keadaan melupakan Allah (Brown, 2011, p. 154).

Karena itulah bagi Schleiermacher Yesus Kristus tidak datang ke dalam dunia untuk menebus dosa melainkan untuk menjadi guru atau model/teladan bagi manusia. Karya penebusan Yesus Kristus hanyalah sekedar untuk membangkitkan kesadaran bahwa manusia berdosa dan tidak berdaya sedangkan Yesus Kristus adalah sempurna sepenuhnya dan tanpa dosa. Karya penebusan Yesus Kristus adalah menarik orang-orang yang percaya ke dalam kuasa kesadaran-Nya akan Allah. Hal ini bukan berarti bahwa penebusan Yesus Kristus dalam rangka menanggung dosa-dosa manusia untuk menyelamatkan manusia, melainkan hanyalah menggerakkan manusia sehingga pengalaman Yesus Kristus dapat dimiliki oleh manusia juga (Brown, 2011, p. 155).

Di dalam Yesus Kristus, manusia mencapai hakikat kemanusiaan-Nya. Jadi menurut Schleiermacher, keselamatan manusia bukan terjadi oleh karena melalui penebusan darah Yesus Kristus, melainkan Yesus Kristus hanya sebagai penebus "model" atau teladan yaitu pengalaman-Nya bisa menjadi pengalaman setiap manusia. Yesus Kristus juga sebagai Penebus dalam arti bahwa Dia mengajar manusia untuk mempraktekkan bagaimana hidup dalam ke- sadaran rohani (spiritual consciousness) yang sempurna. Dengan melakukan atau mempraktekkan sendiri, maka akan menolong manusia untuk mengambil bagian dalam pengalaman tersebut. Dengan demikian, Yesus Kristus sebagai Penebus adalah sama dengan guru yang memberi teladan dan mengajar (educative influence as a continuation of the devine) (Susabda, 1990, p. 26).

Dengan memandang Yesus Kristus sebagai penebus model atau teladan, bukan sebagai pengganti atau pendamaian atas dosa manusia maka kemudian Schleiermacher menganggap bahwa dalam ajaran Kristen tidak lagi diperlukan kepercayaan terhadap kebangkitan, kenaikan dan kedatangan Yesus Kristus kembali untuk menghakimi manusia. Percaya maupun tidak terserah kepada penilaian manusia atas kebenaran Alkitab (Berkhof, 1994, pp. 118-119; Lane, 2012, pp. 200-201).

\section{Analisis Terhadap Teologi Schleiermacher}

Sebagaimana yang telah dipaparkan di atas bahwa metode berteologi dari Schleiermacher berada dalam persimpangan jalan (cross road) dan pengaruh dari beberapa aspek. Pengaruh dari ayahnya sebagai pendeta gereja Reformed (Calvinist) yang sangat menekankan Alkitab (Sola Scritura/Tota Scriptura) sebagai sumber berteologi, ajaran Kristen dan praktik iman Kristen secara normatif dan idealist. Demikian juga dengan semangat gerakan kebangunan rohani Pietisme-Moravian yang menekankan kesalehan hidup dan pengalaman iman Kristen yang nyata (real) bukan sekedar pengetahuan akan doktrin maupun dogma yang benar (ortodoksi) melainkan dibarengi dengan praktek kehidupan (ortopraksi) dan pelayanan yang benar. Sekalipun demikian, Schleiermacher tidak merasa puas dengan kekristenan "tradisional" tersebut, maka ia juga melakukan petualangan dengan mempelajari tulisan-tulisan filsafat, baik klasik seperti tulisan Plato maupun moderen seperti tulisan Immanuel Kant.

Semangat zaman yang menggilas belahan Eropa akibat dari pencerahan (age of reason/Enlightenment/Aufklarung) juga memperhadapkan Schlei- 
ermacher dengan orang-orang yang mempertuhankan akal budi (rasionalisme) sekaligus menentang rasionalisme dengan menuntut realitas kehidupan secara eksistensial yakni romantisisme. Kelihatannya Schleiermacher tidak mau tertawan dengan kekristenan yang kering yang hanya berdasarkan Alkitab maupun penjelasan-penjelasan doktrinal atau dogmatisme yang kaku yang hanya memuaskan akal budi manusia. Schleiermacher agaknya mengupayakan suatu teologi yang dapat menjawab bagaimana manusia bisa mengalami pengalaman dengan Allah yang tidak sekedar sebagai hasil konstruksi sejarah masa lalu melainkan realitas masa kini. Dalam hal ini Schleiermacher dapat memberikan kontribusi positif dalam teologi Kristen, bahwa Tuhan memang nyata dan bukan sekedar perkataan orang, apalagi rumusan pemikiran para teolog pada masa lalu. Karena itu, beberapa hal secara positif maupun negatif akan diuraikan dalam pembahasan di bawah ini suatu evaluasi kritis mengenai pandangan teologi atau metode berteologi dari Schleiermacher.

Schleiermacher berangkat dari metode berteologi yang tidak terlepas dari agama, sebab baginya agama merupakan bahan material yang kemudian diolah menjadi teologi. Schleiermacher ada benarnya pada saat ia berpendapat bahwa agama tidaklah didapati di dalam rumusan-rumusan dogma dan doktrin atau sistem teologi, sebab memang agama yang sejati adalah realitas hubungan manusia dengan Penciptanya, bahkan lebih tepat lagi merupakan totalitas hubungan antara Pencipta dengan ciptaan. Kerapkali rumusan-rumusan dogma begitu kaku dan kering apabila hanya sekedar memberi wawasan mengenai asal mula dan akhir dunia serta pemaparan mengenai keberadaan (being) realitas yang begitu abstrak sehingga sulit untuk dipahami. Akan tetapi bukan berarti dengan demikian harus meniadakan dogma atau doktrin, sebab apabila doktrin maupun sistem teologi merupakan refleksi dari penyataan/wahyu Tuhan yang bersumber dari Alkitab, maka justru doktrin adalah pedoman yang harus diajarkan, dihayatim diresapi, dihidupi, dan dilakukan oleh setiap manusia. Adalah membaha- yakan apabila, tidak terdapat garis pedoman (seperti doktrin) dalam manusia beragama, yang mengakibatkan manusia akan terjerumus kepada pemahaman dan kehidupan yang seperti melompat dalam gelap.

Pendapat Schleiermacher yang menekankan bahwa agama pada esensinya ditemukan di dalam ranah perasaan (feeling) memang terdapat kebenaran. Apalagi menurutnya, yang dimaksudkan dengan perasaan tidak sekedar rasa, emosi, atau sensasi melulu, melainkan perasaan ketergantungan mutlak/ feeling of absolute dependencyterhadap sesuatu yang tidak terbatas, yang kekal atau Allah. Suatu perasaan yang diakibatkan karena penjumpaan dengan sesuatu yang tidak terbatas di dalam yang terbatas (Sulistio, 2004 , p. 159). Kehidupan beragama yang hanya memberi ruang kepada ide-ide atau wawasan-wawasan rohani/teologi, tanpa adanya pengalaman perasaan adalah sesuatu yang kering. Apalagi kehidupan beragama yang hanya sekedar teori-teori yang lahir dari pemikiran atau pergulatan akal budi hanyalah filsafat yang kosong. Akan tetapi penekanan yang terlalu berlebihan kepada perasaan dalam kehidupan beragama akan menyebabkan subyektifitas dalam pengalaman beragama. Adapun pengalaman "jiwani/psikis" tidak sama dengan pengalaman rohani/spiritual. Sesuatu yang berkaitan dengan feeling atau merasa beriman, berbahagia, tersentuh dan perasaan luapan keagamaan lainnya adalah gejala psikologi yang tidak selalu merupakan manifestasi dari pengalaman rohani dengan Tuhan. Aliran-aliran kebatinan di luar kekristenan juga menyediakan berbagai latihan meditasi yang bisa menghasilkan "pengalaman jiwa" yang menyenangkan perasaan. Namun sesungguhnya pengalaman psikologi tersebut tidak sama dengan pengalaman rohani yang terjadi karena penjumpaan/encountering dengan kebenaran Firman Tuhan. Pengalaman rohani yang sejati tidak pernah dialami oleh manusia di luar kaitannya dengan kebenaran Firman Tuhan seperti yang dinyatakan Alkitab. Kebenaran Firman Tuhan yang fokusnya terdapat realitas sejarah bahwa Allah telah menjadi manusia, disalibkan, mati dan dibangkitkan kembali. Karya penyelamatan Allah yang hanya di- 
pahami dan dipercaya oleh manusia karena pekerjaan Roh Kudus melalui kelahiran kembali dan pengudusan oleh-Nya (Susabda, 1990, pp. 27-28).

Pemahaman Schleiermacher mengenai Alkitab seolah-olah merupakan upaya untuk menjauhkan diri dari pemahaman teologi natural yang menekankan ide-ide dan rasionalisasi agama. Memang tidak ada salahnya, apabila Schleiermacher meyakini bahwa Alkitab memuat tokoh-tokoh dan peristiwa-peristiwa yang menceritakan pentingnya kesadaran dan perasaan ketergantungan mutlak/feeling of absolute dependency kepada Allah. Akan tetapi sangat berbahaya apabila Alkitab lebih diperlakukan sebagai riwayat pengalaman keagamaan manusia ketimbang sebagai penyataan (wahyu) Allah (Lane, 2012, p. 200). Hal ini akan membuat Alkitab tidak jauh berbeda dengan buku-buku dan dokumen-dokumen sejarah tertentu yang mengisahkan kepahlawanan ataupun peristiwa-peristiwa penting sehingga melupakan kenyataan bahwa penulis Alkitab adalah Allah sendiri. Alkitab adalah Firman Allah, penyataan Allah mengenai kehendak-Nya terlebih Alkitab menegaskan mengenai tindakan-tindakan Allah dalam sejarah. Karena itu, sekalipun begitu penting pengalaman para tokoh dan peristiwa yang tercatat dalam Alkitab, namun Alkitab sesungguhnya merupakan tolak ukur berdasarkan kehendak Allah akan semua pengalaman manusia termasuk pengalaman manusia dengan Tuhan.

Penekanan Schleiermacher berkaitan dengan doktrin Allah bahwa Allah adalah obyek dari perasaan bergantung mutlak pada diri manusia juga menimbulkan kesulitan apabila dipisahkan dari Allah yang telah menyatakan diri melalui Firman Tuhan/ Alkitab. Allah yang mana yang dimaksudkan oleh Schleiermacher? Penekanan Schleiermacher terhadap perasaan/kesadaran dan pengalaman sehingga menyingkirkan dogma dan doktrin dari kehidupan beragama akan membuka kesempatan untuk mempercayai Allah yang sembarangan saja. Sesungguhnya Schleiermacher tidak lagi membicarakan mengenai bahasa Teisme Kristen dalam berteologi. Dalam pandangan teologi Kristen yang konservatif,
Allah adalah pribadi yang menguasai dunia, yang sempurna di dalam diri-Nya sendiri, merupakan pencipta dan penopang segala sesuatu yang secara aktif memperhatikan dan terlibat dalam pergumulan dunia, hadir di dalam dunia namun tidak bergantung pada dunia dan ciptaan. Akan tetapi Schleiermacher membicarakan Allah bukan sebagai "pribadi di luar" ciptaan melainkan sebagai "diri pribadi itu sendiri" atau "dasar dari pribadi". (Brown, 2014, pp. 157158).

Bagi Schleiermacher, atribut-atribut Allah sebagaimana yang menjadi doktrin-doktrin mendasar dalam kekristenan berasal dari refleksi terhadap pengalaman atau perasaan kebergantungan mutlak/ feeling of absolute dependency kepada-Nya. Konsep mengenai kekekalan, kemahadiran, kemahakuasaan, kemahatuan dan penciptaan sebagai atribut dari Allah berasal dari perasaan kebergantungan mutlak kepada Allah (Sulistio, 2004, p. 162). Berarti manusia (perasaan/kesadaran/pengalaman manusia) yang menentukan atribut-atribut dari Allah bukan karena penyataan atau penyingkapan diri Allah melalui Alkitab? Dengan demikian manusia pada kadar tertentu menjadi patokan/kanon dalam menilai dan menyimpulkan kebenaran mengenai Allah dan atribut-atribut-Nya. Tentu saja hal ini cenderung membahayakan sebab tidak seperti yang dinyatakan melalui Alkitab mengenai kesempurnaan Allah di luar ciptaan.

Seperti yang telah diuraikan di atas bahwa pandangan Schleiermacher mengenai pribadi maupun karya Tuhan Yesus Kristus adalah berbeda dengan pandangan ortodoks. Bagi Schleiermacher (1998; 2002), Yesus Kristus adalah manusia superman dan superpower namun hanya sebatas guru atau model/teladan bagi manusia lainnya. Menurutnya, Yesus Kristus bukan Allah hanya manusia biasa yang mana Allah hadir dalam hidupNya. Tentu saja keyakinan seperti ini tidak sesuai dengan Kristologi Alkitabiah yang menegaskan bahwa Yesus Kristus adalah Allah (misalnya dalam Yohanes 1:1).

Akibat terlalu menekankan Yesus Kristus sebagai model atau guru, maka Schleiermacher juga terjebak kepada pandangan bahwa karya penebusan 
Kristus adalah sekedar contoh bagi manusia lainnya. Dengan demikian Schleiermacher bukan saja menyingkirkan karya keselamatan yang telah dikerjakan oleh Tuhan Yesus Kristus melalui pengorbanan darah-Nya di kayu salib, namun mencoba menjadikan manusia menjadi juruselamat bagi diri sendiri melalui potensi diri yang bisa meneladani karya penebusan Yesus Kristus.

Keyakinan Schleiermacher bahwa Yesus Kristus sebagai seorang manusia yang memiliki pengalaman tingkat tinggi pada satu sisi seolah-olah menyatakan bahwa Yesus Kristus berbeda dari tokoh manusia manapun. Akan tetapi pada sisi yang lain, justru mencoba untuk menghilangkan eksistensi dan realitas Yesus Kristus sebagai Allah yang telah menjadi manusia. Demikian pula dengan keyakinan Schleiermacher bahwa signifikansi Yesus Kristus bukanlah suatu realitas bahwa Dia menanggung hukuman dosa demi manusia melainkan hanya sebatas kesadaran akan Allah serta melalui kebergantungan Yesus Kristus yang mutlak akan Allah mampu menyalurkan kesadaran tersebut kepada manusia-manusia lainnya. Dengan keyakinan seperti ini, Schleiermacher justru telah menyingkirkan keunikan dan keistimewaan kekristenan Alkitabiah yang mempercayai bahwa Yesus Kristus adalah satu-satunya jalan keselamatan sebab Ia telah memberikan nyawa-Nya untuk menjadi tebusan bagi manusia berdosa.

Schleiermacher juga tidak mempercayai pengajaran Kristen mengenai realitas dosa sebagai sifat dasar (nature) semua manusia yang merupakan pemberontakan terhadap Allah. Schleiermacher hanya sekedar membatasi pengertian dosa sebagai sesuatu yang mengganggu perasaan bergantung mutlak di dalam diri manusia. Dengan kata lain dosa diartikan sebagai keinginan manusia untuk bebas pada saat yang seharusnya bersatu dengan Allah (Brown, 2014, p. 158). Dengan demikian bagi Schleiermacher, dosa bukanlah natur semua manusia yang telah terpisah dari Allah dan pada dasarnya manusia telah mati secara rohani. Manusia bisa mengatasi dosa dengan sendirinya apabila memiliki kesadaran untuk bergantung secara mutlak kepada Allah. Sehingga manusia manapun tidak memerlukan seorang Penebus atau Juruselamat. Manusia tidak membutuhkan lagi pertolongan di luar dirinya sendiri, melainkan hanya membutuhkan kesadaran/perasaan/pengalaman untuk "bertobat sendiri". Dengan kata lain bagi Schleiermacher, sebenarnya manusia tidak membutuhkan Allah.

Demikian pula terkait dengan pemahaman mengenai keselamatan bagi Schleiermacher hal itu tidaklah sama dengan kehidupan kekal di surga karena jasa penebusan Yesus Kristus melainkan keberadaan manusia yang telah mencontoh Yesus Kristus sebagai teladan atau model dalam kebergantungan mutlak kepada Allah. Adapun bagi Schleiermacher, keselamatan bukan pembebasan dari kuasa dan hukuman dosa melainkan pengalaman berbagi (sharing) antara Yesus Kristus dengan manusia yang mau meneladani-Nya.

Tentu pandangan teologi Schleiermacher begitu radikal sebab sangat berbeda dengan pengajaran Alkitab maupun rumusan-rumusan doktrin Kristen tradisional. Akan tetapi, pada sisi lain juga masih terdapat banyak hal yang positif dengan pandangan teologinya yang menekankan perasaan dan pengalaman dengan Tuhan. Sebab apabila teologi hanya berupa ajaran-ajaran yang memuaskan akal budi sebagaimana yang nampak dalam filsafat, maka teologi tersebut tidaklah relevan. Schleiermacher berupaya memasuki bagian empiris dari dunia teologi yang cenderung abstrak. Hanya saja sangat berbahaya apabila sikap empiris tersebut tidak dibarengi dengan hermeneutika Alkitab yang ketat serta doktrin yang benar. Manusia akan terjerumus pada psikologi agama dari pada teologi. Hal ini nampak pada penekanan Schleiermacher terhadap faktor kebergantungan mutlak/ feeling of absolute dependency kepada Allah sebagai penentu kehidupan beragama. Hal ini juga mencakup pandangan Schleiermacher terhadap Alkitab yang hanya sebatas kitab pengalaman keagamaan. Apabila tanpa penelitian, penafsiran dan penerapan yang benar mengenai aspek feeling of absolute dependency dalam terang Alkitab maka akan menyebabkan pengalaman keagamaan 
atau iman manusia seperti seseorang yang melompat dalam gelap. Alkitab menegaskan bahwa iman timbul dari pendengaran akan Firman Kristus (Rom. 10:17).

Pertanyaan maupun pernyataan Schleiermacher mengenai relevansi agama atau iman Kristen, termasuk relevansi Pribadi Tuhan adalah sesuatu yang berharga karena baginya Tuhan adalah pribadi yang real, maka pengalaman manusia dengan Tuhan seyogyanya juga real. Akan tetapi mencari sekedar relevansi tanpa sumber referensi yang benar (Alkitab) terutama mengenai Tuhan yang telah menyatakan diri didalam Alkitab, yaitu Allah di dalam Yesus Kristus maka tanpa Alkitab sebagai referensi maka kekristenan hanya akan terseret pada tingkah laku beragama.

Adapun pemikiran teologi Schleiermacher adalah hasil dari semangat zaman yang menjadi realitas pada zaman moderen yang selalu terjadi pergulatan antara teks dan konteks, teori dan praktek, abstrak dan konkrit, norma dan pengalaman, serta ide dan kenyataan. Sejarah Gereja kerap menyatakan bahwa apabila kekristenan jauh dari Alkitab dan kompromi dengan semangat zamannya, maka semangat zaman itu akan mengendalikan kekristenan. Karena itu, penting sekali kekristenan untuk kembali kepada Alkitab sebagai sumber berteologi, menghayati kehidupan dan kesaksian, namun juga tetap melek terhadap kenyataan dan pergumulan hidup di dunia ini

\section{KESIMPULAN}

Dengan menguraikan mengenai analisa terhadap teologi Schleiermacher di atas, kita dapat melihat hal-hal positif dari pemikiran teologinya yang senantiasa dipengaruhi oleh semangat zaman tertentu dan mempengaruhi teologi sampai zaman postmoderen ini. Adalah bijaksana untuk terus belajar bahwa pentingnya pengalaman (experience) dalam kekristenan untuk tetap setia terhadap Alkitab namun relevan dengan konteks kehidupan. Karena de- ngan demikian kekristenan dapat tampil sesuai hakikatnya sebagai garam dan terang dunia (Mat. 5:1316).

Pada akhirnya melalui pembelajaran terhadap Schleiermacher dan pemikiran teologinya maka dapat dipahami begitu pentingnya pengalaman dalam kekristenan. Bukankah dalam dogma kekristenan menegaskan bahwa setiap orang yang mempercayai Tuhan Yesus Kristus sebagai Tuhan dan Juruselamat dipersatukan dengan Dia (union with Christ)? Lagi pula dalam kekristenan tidak sekedar hanya terdiri dari formulasi doktrin maupun kredo tertentu yang telah dirumuskan dalam rangkaian konsili (ortodoksi) melainkan disertai dengan pengalaman yang hidup dengan Allah yang hidup maupun dengan sesama manusia (ortopraksi). Yang terpenting lagi, kekuatan dalam kekristenan justru menekankan mengenai Allah yang hidup seperti yang telah dinyatakan dalam Alkitab adalah Allah yang tidak hanya dapat dijangkau dengan philosophia atau wisdom. Dia adalah Allah Yang Mahatinggi (transcenddence) namun telah berkenan menjadi daging di dalam Tuhan Yesus Kristus sehingga bisa beserta dengan manusia (immanence). Bukan manusia yang telah mencari Allah, namun Allah yang telah mencari dan menjadi manusia serta memasang kemah untuk tinggal dalam persekutuan dengan umat-Nya (Yoh. 1:14). Kehadiran Roh Kudus yang tinggal di dalam hidup manusia dan telah menjadikan manusia sebagai Bait-Nya adalah bukti bahwa Allah ingin bergaul dengan manusia serta realitas kebutuhan manusia untuk senantiasa bergantung kepada-Nya.

Dengan demikian Friedrich Schleiermacher dalam pemikiran teologisnya mengingatkan kembali kepada kekristenan masa lalu dan kini serta yang akan datang mengenai pentingnya Sola Experientia (hanya pengalaman) dalam berteologi yang melengkapi legacy para reformator yaitu Sola Christo, Sola Gratia, Sola Fide, Sola Scriptura dan Soli Deo Gloria. 


\section{DAFTAR RUJUKAN}

Berkhof, Louis. 1994. The History of Christian Doctrines. Grand Rapids, Michigan: Baker Book House.

Brown, Colin. 2011. Filsafat dan Iman Kristen 1. Surabaya: Penerbit Momentum.

Brown, Colin. 2014. Filsafat dan Iman Kristen 2. Surabaya: Penerbit Momentum.

Collins, Michael. 2006. The Story of Christianity. Yogyakarta: Penerbit Kanisius.

Daun, Paulus. 2000. Apakah Liberalisme dan Moderenisme Itu?. Manado: Yayasan Daun Family.

Daun, Paulus. 2010. Teologi Kontemporer. Manado: Yayasan Daun Family.

Hadiwiyono, Harun, 2000. Teologi Reformatoris Abad Ke 20. Jakarta: BPK Gunung Mulia.

Hardiman, Budi F. 2015. Seni Memahami, Hermeneutik Dari Schleiermacher Sampai Derrida .Yogyakarta: Kanisius.

Hoffecker, W. Andrew. 2017. Revolusi-Revolusi dalam Wawasan Dunia-Memahami Arus Pemikiran Barat. Surabaya: Penerbit Momentum.

Horton, Michael. 2004. Christian Faith: A Systematic Theology for Pilgrims on the Way. Grand Rapids, Michigan: Zondervan.

Lane, Tony. 2012. Runtut Pijar: Sejarah Pemikiran Kristiani. Jakarta: PT BPK Gunung Mulia.
Naugle, David K. Wawasan Dunia: Sejarah Sebuah Konsep (Sebuah Pandangan Kristen). Surabaya: Penerbit Momentum.

O'Donnell, Kevin. 2015. Sejarah Ide-Ide. Yogyakarta: Kanisius.

Schleiermacher, F. 1996. On Religion Speechs to its Cultured Despisers. Cambridge: Cambridge University Press.

Schleiermacher, Friedrich. 2002. Lectures On Philosophical Ethics. Cambridge: Cambridge University Press.

Smith, Linda \& William Raeper. 2011. Ide-Ide Filsafat dan Agama Dulu dan Sekarang. Yogyakarta: Kanisius.

Sulistio, Christian. 2004. "Perbandingan Metode Berteologi F.D. Schleiermacher Dan Alister McGrath." Veritas: Jurnal Teologi dan Pelayanan, 5 (2).

Susabda, Yakub. 1990. Seri Pengantar Teologi Moderen I. Jakarta: Lembaga Reformed Injili Indonesia.

Urban, Linwood, 2003. Sejarah Ringkas Pemikiran Kristen. Jakarta: BPK Gunung Mulia.

Wellem, F.D. 2011. Riwayat Hidup Singkat TokohTokoh Dalam Sejarah Gereja. Jakarta: PT BPK Gunung Mulia. 